\title{
Chapter 5 \\ From Everyday Racist Incidents at Work to Institutional Racism: Migrant and Minority-Ethnic Workers' Experiences in Older-Age Care
}

\author{
Nina Sahraoui
}

\subsection{Introduction}

If you see somebody oppressing someone, you have to speak up or if you can't do anything, in your mind you have to be against it. But if you just sit down and watch, this makes you also a sinner, you understand? If you bear oppression, and if you don't fight it, you also make a big sin, that's why we have always to fight, we have to. Wherever you are, life is not easy, it's always a challenge, always. This will make you stronger. What about you, are you a fighter? (Sameera, 32, Mauritius, London).

Sameera had lived in the UK for 12 years when we met. She came from Mauritius, where she had been working in a pharmacy. On arrival in London she again found employment in a pharmacy, though in a lower position. For 4 years she did not have a single day of annual leave; she felt exhausted, left the job and looked for something else. She found a job as a care assistant in older-age residential care. In her new employment she again went through tough times; she was harassed by colleagues and felt discriminated against by her managers. Immersed in these unpleasant memories during the interview, Sameera made the statement quoted above. Seen as an individual experience, Sameera's narrative appears to be specific and personal. Analysed as part of an institutional context shaped by employment rights, migration policies and anti-discrimination legislation and practice, such narratives reveal how these experiences reflect differentiated forms of institutional racism.

Through the analysis of non-EU migrant' and minority-ethnic care workers' narratives around their experiences and perceptions of racism and discrimination within older-age care in London, Paris and Madrid, this chapter attempts to shed light on some of the mechanisms fostering disintegration. It addresses in this regard what is at the heart of integration - equality of both access and outcome for migrants and racialised minorities - named by the editors of this volume 'equal participation in social systems' (Collyer et al. 2020). The chapter does not focus on the concept of

N. Sahraoui $(\square)$

GTM-CRESPPA, Paris, France 
integration per se (see also Nimführ et al. 2020; Chap. 9) but, rather, on racism and racist discrimination (the distinction between racism and discrimination is clarified below). Engaging the material implications of racism contributes, this chapter argues, to our understanding of some of the exclusionary processes leading to disintegration. Exploring the dynamics of labour-market segmentation outlines a form of systematic discrimination - and thus of institutional racism - against racialised workers through migration and employment policies that produce deskilling and entrapment. The literature on migrant domestic workers foregrounded in this regard the racist structures upon which this segmentation relies (Ehrenreich and Hochschild 2002; Parrenas 2000). As noted by Collyer et al. (2020, p. 5) 'The disproportionate inclusion of migrant workers in particular sections of the labour market [...] may make their exclusion from various other domains of social and everyday life more likely'. More precisely, this chapter illustrates how labour-market segmentation translates into everyday experiences of disintegration for migrant and minorityethnic workers. It seeks to bring out how these experiences, on the one hand, and respondents' ways of coping with them on the other, inform the 'ruling relations' (Smith 2005) that characterise respondents' work environments. This method of inquiry 'works from the actualities of people's everyday lives and experience to discover the social as it extends beyond experience' (Smith 2005, p. 10). In this regard, respondents' daily experiences and collective responses are central to the analysis.

In this chapter I demonstrate that anti-discrimination legislation often remains out of reach for racialised precarious workers and thus argue that anti-racism is too often reduced to the legal framework of anti-discrimination policies, falling short of analysing the structural dynamics that foster racism at multiple levels. The focus on cases of racism by colleagues and managers informs our understanding of how policies and institutions can produce disintegration, a process nonetheless enacted by individuals. Like Schweitzer (2020), who traces how immigration control mechanisms increasingly run through education- and health-related institutions, I equally highlight neglected dimensions of how practices that foster exclusion manifest themselves within specific workplaces. Following a brief description of the methodology, the first section situates the concepts of racism, racialisation and racist discrimination as understood here and briefly presents how anti-discrimination policies are implemented in each of the three countries relevant to this chapter. This overview contextualises the specific environments within which experiences of racism and discrimination take place. The second section empirically explores cases of racist behaviour by colleagues and of harassment/discrimination by managers. It highlights that, against the background of contemporary manifestations of racism in interpersonal interactions being less overt, victims of racism often feel insecure about their ability to challenge such forms of racism. In addition, in the cases under study, managers tolerated the described manifestations of racism or sided with the dominant group. The section equally examines how managerial practices were at times directly discriminatory, ranging from unfair workloads to bullying and stigmatisation. The last section explores how workers coped with racism and racist discrimination and why these situations were particularly difficult to challenge legally. 


\subsection{Methodology}

This chapter is based on fieldwork conducted in London, Paris and Madrid between December 2013 and January 2015. The three European capitals chosen for this research represent three urban centres of significant size that are, in many ways, at the forefront of modern societies' 'crisis of care' (Fraser 2016). At the same time, these three locations are embedded in significantly different migration, employment and care regimes (Williams 2012). The findings presented here build upon 83 interviews conducted with non-EU migrant and minority-ethnic care workers in these three European capital cities. Rather than adopting a systematically comparative approach, the chapter focuses on drawing links between respondents' experiences across contexts so as to provide insights into the shared patterns of racism in the workplace that underpin the chapter's overall argument.

In the UK and Spain, interviewees were working as (health-) care assistants (in some cases live-in). In France, three different statuses corresponded to this position in terms of daily tasks performed: life assistant (auxiliaire de vie), medical/psychological assistant (aide médico-psychologique) and healthcare assistant (aidesoignant). The interviews took place in coffee shops as well as in care homes, mostly behind closed doors. I usually spent several hours in a home on one visit and was immersed into the workplace atmosphere, observing daily working routines in the lounges and corridors. The interviews lasted from $35 \mathrm{~min}$ to more than $2 \mathrm{~h}$ and were about $1 \mathrm{~h}$ on average. All interviews were recorded and transcribed. Qualitative data analysis software was used for coding and analysing the collected data following thematic analysis (Boyatzis 1998).

\subsection{Racialisation, Institutional Racism and Anti- discrimination Policies}

While this chapter makes a strategic use of the concept of 'minority ethnic' (Aspinall 2002) in the spirit of the 'intercategorical complexity' (McCall 2005) within intersectional studies, the concepts of 'process of racialisation' and 'racialised groups' are here preferred in an attempt to capture the social process at work without granting 'ethnicity' or 'race' a material existence but acknowledging the sociological implications of the existence of both concepts as well as the role 'ethnicity' plays in struggles for recognition. This focus on racialisation as process is crucial given that the definition of what constitutes racism cannot be static either. Stuart Hall wrote: 'Racism [is] not a permanent human or social deposit which is simply waiting there to be triggered off when the circumstances are right' (Hall 1978, p. 26). Gilroy warns in an analogous way against interpretations which do not recognise that racism 'exists in plural form, and I have suggested that it can change assuming different shapes and articulating different political relations' (Gilroy 1987/2002, p. 42). The notion of 'total social phenomenon' forged by Balibar furthermore highlights 
that racism is to be found in everyday practices, discourses and imaginaries (Balibar and Wallerstein 1988). From this perspective, racist discrimination implies a practice and thus differs from the concept of racism, which entails a broad range of possible manifestations - racist discrimination constituting one of these.

The relationship between ideology and practice - or the question of intentionality - also needs to be clarified. The 'race relations' model of British sociology tended, for instance, to focus on personal prejudice up to the mid-1970s. Similarly, philosophical accounts of racism tend to put the issue of intentionality at the heart of the definition of racism, referring for instance to 'motivational racism' (Headley 2000). This is not, however, the assumption on which this chapter relies. Following Anthias and Yuval-Davis (1992, p. 13), it is accepted here that 'racist practices do not require the racist intentionality of structures (...). Practices may be racist in terms of their effects'. In a nutshell, racist discrimination can result from policies and practices, which might or might not be imbued with explicit racist ideology. In that sense, the concept of 'institutional racism' - developed to a much greater extent in the Anglo-Saxon literature than in French and Spanish studies of racism - proves to be particularly useful for conceptualising racist outcomes without systematic racist intentionality. Early conceptualisations of institutional racism are to be found in the Black Power movement and notably in Carmichael's writings (Carmichael and Hamilton 1967/1992). Later, Sivanandan (1985) distinguished between what he named 'racialism' - defined as prejudice displayed by individuals - and racism understood as structural racism. At the heart of this oppression are power relationships, as stated by Ikuenobe (2010, p. 162): 'Not all forms of racial discrimination or prejudice may be characterized as racism. In order for racial discrimination or prejudice to be characterized as racism, it must involve social-political power'. Experiences lived by racialised workers are here analysed as racist in the sense that 'Xenophobia, or the dislike of the stranger or outsider, (...) becomes racism when there are power relations involved. These can then put into practice the sentiments of antipathy and produce racist effects' (Anthias and Yuval-Davis 1992, p. 12).

The assumption that we live in post-racial societies de facto obscures the continuity of 'race' as an organising dynamic in European societies. The political economy of the Western world is increasingly shaped by neoliberal values and, under neoliberal governmentality, 'everyone is expected to have full personal responsibility'; as a consequence, everyone risks a 'loss of right for a life mismanaged' (Lentin and Titley 2011, p. 163). While capitalist structures of production rely intrinsically on socially constructed divisions among people - including processes of racialisation - these stratifications are effectively covered up by a governmentality (Foucault 2004) that constructs the illusion of neutrality. Neoliberalism is perceived not as a 'particular set of interests and political interventions, but as a kind of nonpolitics' (Duggan 2003, p. 10). This obscures power relationships at work and forms of oppression on which neoliberalism relies and which shape the everyday life experiences of women, racialised groups and other minorities. 
From this perspective, the paradox of anti-discrimination policies implemented alongside institutionally ingrained racist discrimination is only superficial. The system of values upon which neoliberalism relies effectively organises the ignorance of those in privileged positions. When the British government states for instance 'You're legally protected from discrimination by the Equality Act 2010'1 it certainly aims at emphasing equal rights and opportunities. Yet, by assuming the existence of equal opportunities, meritocracy constrains our understanding of racism. While antidiscrimination regulations might be useful for challenging certain manifestations of racism, it also allows for a naturalisation of inequalities within society. If anti-discrimination legislation ensures that anyone can denounce discrimination, then everyone is held responsible for his/her individual position in the labour market and in society at large. Anti-discrimination policies pertain to the politics of diversity under neoliberal governance and are central to contemporary understandings of integration. The inclusive aspiration of anti-discrimination legal measures obscures the very unequal conditions of access to these rights. Unpacking the paradox of states' commitment to anti-discrimination alongside the reproduction of institutionalised forms of racism thus sheds light on (dis)integration processes. This chapter critically assesses the shortcomings of the anti-discrimination legislation and its associated discourse of equal opportunities. The situated perspective of racialised workers in older-age care reveals how anti-discrimination can thrive at the policy level while the political economy of society reproduces major inequalities along gendered and racialised lines of division. The following paragraphs provide insights into the practice of anti-discrimination legislation for the three national contexts relevant here.

In the UK, 3064 racial discrimination claims were lodged with employment tribunals in 2013-2014 (Thelwell 2015). The number of claims decreased after the government introduced claim and hearing fees in 2013; 5700 claims were lodged in 2009-2010 (Ministry of Justice 2012). Discrimination cases are the most expensive, claim and hearing fees reaching $£ 1200$ compared, for instance, with $£ 410$ for cases of unpaid wages (Department for Business Innovation and Skills 2014). To add to this, only a minority of employment tribunal cases progress to full hearings; most cases are either settled by the Advisory, Conciliation and Arbitration Service (33\% in 2010-2011), withdrawn (27\%) or struck out (13\%) (Ministry of Justice 2012). Once at the hearing stage, cases of racial discrimination have the poorest chances, with a success rate of only 16\% in 2010-2011 (Renton 2013). In his online article, published by the Institute of Race Relations, Renton (2013) questions why racial discrimination cases are so unlikely to be successful, compared not only to unfair dismissal or wage deduction cases but also to other discrimination cases - such as sex discrimination (37\%) or sexual orientation discrimination (26\%). On the basis of several case studies, he points out that the understanding of racial discrimination is often conflated with racist intentions by judges. It is therefore not enough for the concept of institutional racism to be discussed within the field of anti-discrimination policies - as is the case in the UK - for the judiciary to take into account its implica-

${ }^{1}$ https://www.gov.uk/discrimination-your-rights 
tions for individual cases. Racial discrimination often remains equated with the racist intentions of the perpetrator and cases tend to revolve around proving or dismissing racist intentions instead of establishing the existence or non-existence of discrimination.

In France, insights into the figures published by the High Authority for the Fight against Discrimination and for Equality (HALDE), ${ }^{2}$ an institution created in 2005 to comply with EU requirements, show that the number of complaints increased from 1410 in 2005 to 12,467 by 2010 . The purpose of this state-funded body was to assist victims of discrimination by supporting their legal fights after the HALDE had reviewed the case and established that discrimination had, indeed, taken place. Around half of these complaints concerned employment and, overall, between 2005 and 2009, 28.5\% of them mentioned 'discrimination based upon ethnic origin' (HALDE 2010). Rattansi (2011) notes, however, that far fewer resources were provided to this new agency than to the former British Commission for Racial Equality. Moreover, the HALDE existed for only a few years, having been integrated in 2011 into an institution with a broader mandate, 'Défenseur des Droits', chaired by an 'Ombudsman', also in charge of children's rights, public service users' rights and security ethics. The merger of the HALDE has been vigorously criticised by grassroots organisations; it appears that information accessible by victims of discrimination is limited and legal cases are no longer published online, nor are the success rates of discrimination cases publicly available, contrary to the practice formerly put in place by the HALDE.

In Spain, as in the UK and France, there exists an immense gap between the extent of discrimination - as subsequent studies have demonstrated (Colectivo Ioé 2003) - and actual legal cases. Anti-discrimination legislation was introduced only in the last decade and the economic crisis affected the state's capacity to implement related programmes. For instance, the Council for the Promotion of Equal Opportunities and Non-Discrimination on the Ground of Ethnic and Racial Origin, created in 2007, only registered 167 individual cases of discrimination in 2010 (Ministerio de Sanidad, Política Social e Igualdad 2011) and soon started to lack funding, according to a 2013 report by the European Network Against Racism (Spitálszky 2013). This NGO also highlighted that Spain failed to publish a transparent database of all discrimination cases, so that an assessment of the efficiency of the legislation is hardly possible (Spitálszky 2013).

It seems overall that anti-discrimination legislation is mobilised in a limited number of cases. Focusing on individual rights arguably only offers a very partial way of addressing deeply rooted inequalities which require social change. Antidiscrimination legislation has, furthermore, a differentiated impact along class and gender divisions and the most privileged amongst racialised workers are in a better position to make use of it; thus potentially contributing to the integration of a few while entrenching the marginalisation of many others. The denial of the continued relevance of racialisation processes in contemporary societies and of their social

\footnotetext{
${ }^{2}$ Haute Autorité de lutte contre les discriminations et pour l'égalité, HALDE.
} 
implications for racialised individuals makes it more difficult to identify, understand and challenge institutional racism. The following section provides insights into selected aspects of migrant and minority-ethnic care workers' experiences of racism at work and points out why some elements amount to institutional racism.

\subsection{Everyday Racism at Work Embedded in Power Relationships}

In the three capital cities studied here, about half of respondents recounted experiences of racism and discrimination in relation either to residents, colleagues or management in older-age care. Respondents had to deal with both overt and covert forms of racism. Systematically exposed to racist comments by residents (Sahraoui forthcoming), some of them were also discriminated against or harassed by colleagues and managers (the focus of this chapter). Individual stories equally revealed how different manifestations of racism often take place simultaneously. The empirical section of this chapter focuses on cases of racist behaviour by colleagues and harassment/discrimination by managers and relates the level of individual interactions to the workings of institutions. It provides, on the one hand, insights into the workings of disintegration as it takes place at and beyond the workplace level in the forms of racist discrimination and exclusion, and explores, on the other, the coping strategies that arise at the level of interpersonal relationships.

\subsubsection{Racist Attitudes Amongst Colleagues: Abusive Work Environments}

Respondents in Madrid and London shared negative experiences of colleagues' racist attitudes in the workplace. In Paris, none of the respondents complained about the racist attitudes of work colleagues, which could be partly related to the fact that, in the care homes visited for my fieldwork, racialised workers made up the great majority of the workforce (around 70-90\% as indicated by the nurses in supervisory positions who were interviewed). Facing similar racism on behalf of certain residents might have fostered solidarity amongst workers by creating a shared condition. ${ }^{3}$ An obvious form of negative experience with colleagues, implying racist hierarchies, were remarks - directly addressed to migrant workers - which offended them. Isabel, who had started a Master's degree in the Philippines, felt deeply insulted by her colleagues' comments:

\footnotetext{
${ }^{3}$ Importantly, these contingent data should not suggest that racist attitudes do not arise amongst racialised workers. Racialisation processes are multifold, creating divisions that might equally manifest themselves amongst racialised care workers.
} 
I have experience in the previous job you know there are some people you know... Racists... When I started there they said, one of the carers asked me, because I'm reading a newspaper in front of a resident, then she just asked me, 'Oh can you read English?' I said 'Yes, I can't come here if I don't know how to read English'. 'Oh, I see' ... and then I was using the remote control because one of the residents asked me to turn on the TV and set it on a programme. 'Oh, do you know how to use that?' As if they are thinking I am ignorant or I'm illiterate because I'm foreigner, I don't know... They are just degrading you (Isabel, 37, the Philippines, London).

In this case Isabel perceived her colleagues' remarks as demeaning and as an attempt to belittle her. Often the same feelings were described in relation to more covert attitudes that did not necessarily involve any voiced interaction but had no less farreaching implications. Pedro, who was born in Spain to Guinean parents, described Spanish society as intrinsically racist and explained how he had to learn to navigate a space of social relations systematically imbued with racist prejudice:

Even if you hate me I will know how to get along. That's something that I learned as a little boy - ignore, carry on and keep on living. You can't do anything else, it's not worth it because it's not viable. You can't fight your whole life against something that vast. So at work I've observed it, you see it a lot, a lot. What happens is that then it depends on each person how you deal with it. If you're a person who doesn't put up with this and you can't channel it and ignore it so that you focus on what's really important, then yes you can have problems. Because unfortunately they'll never tell you, very rarely they'll say it openly so that you can justify it, the key is to prove it. So they'll say 'I didn't say anything'. So the best thing is to take it in, deflect it and transform it into something good (Pedro, 25, born in Spain to Guinean parents, Madrid).

In Pedro's account, racist prejudice is diffuse, permanently present but rarely provable. It affects so many of his daily social relations that, even if he is highly aware of the racist overtones of certain attitudes towards him, he feels he can do very little about them, given that this prejudice is not expressed through insults or aggression but through less obvious behaviour, which nevertheless leaves no doubt about its meaning. The following account by Sameera, quoted in the introduction to this chapter, also describes the difficulty of coping with covert forms of racist bullying:

And when I was working I could feel, they wouldn't even look at you while you're sitting, they just move when you come to the staff room, you sit next to them, they move. I was thinking ....what happened? I was thinking maybe I'm smelly... You know? Maybe something is wrong with me, maybe my clothes are dirty...Me I shower every day ...slowly slowly I feel the attitude. Now I start feeling what this is, you know. And then there was a girl over there I will never forget, the way she treats you....how can I say. It's like you're nothing (Sameera, 32, Mauritius, London).

These discriminatory attitudes at work deeply affected Sameera's well-being as her marginalisation became more and more apparent. Her colleagues' behaviour was not, as it might appear, a passive attitude but constituted an active form of bullying. This form of interpersonal interaction illustrates racist prejudice at the individual level. The attitude of Sameera's colleagues can be described as a form of 'aversive racism' (Byrd 2011; Gawronski et al. 2008). Negative feelings towards a racialised person are expressed by such behaviour but no opinion is voiced against egalitarian values per se. The examples given here by Isabel, Pedro and Sameera all reflect the fact that contemporary manifestations of racism in interpersonal interactions tend to 
be less overt because of the stigmatisation of racism in mainstream political and societal discourse and the likelihood of it being sanctioned. Victims of racism often feel insecure about their ability to challenge a form of racism that is not accompanied by racist claims. From this perspective, anti-discrimination legislation risks falling short of addressing the social phenomenon it concerns itself with - this in spite of having reversed the burden of proof in corresponding judicial procedures.

In the Spanish context, Claudia, who had been working in the same care home for 10 years, lamented the discrimination against 'Latino' workers by Spanish colleagues:

At work there's sometimes discrimination, a lot of discrimination. Those who go first for breaks are the Spaniards and, if the Latinos are there, 'What are you doing there?' So what happens? They always have their breaks first, the Spaniards, best things for them and the Latinos are as always left behind (Claudia, 53, Peru, Madrid).

Another form of harmful interaction amongst colleagues is favouritism between minority groups. Mary, for instance, worked in a care home where she was one of the few Black workers (she identified as 'Black British') and where migrant workers from the Philippines represented the numerical majority, including Filipino staff in most managerial positions (except for the manager of the home, who was White British):

In a workplace where we have a lot of different minorities, Black, White, Asians, when there becomes a majority of a certain minority then it starts a little bit of unfairness going on and favouritism ... and which does happen here in (name of the care home) and I'm not gonna lie to you, there is a lot of favouritism here (Mary, 20, Black British, London).

Racist behaviour amongst colleagues should invoke employers' responsibility for ensuring a fair workplace, in that managers' harmful negligence creates abusive environments. However, in none of the cases described above did managers provide support to respondents recounting such experiences. When discriminatory attitudes by colleagues were pervasive, in all the cases in which respondents in this research reported it to their managers, the latter were complicit in that they tolerated it or sided with the dominant group. Workers discriminated against because of favouritism towards other groups of workers did not envisage challenging it formally, often out of fear of retaliation. This factor constituted a very common deterrent to the use of anti-discrimination legislation.

\subsubsection{Discrimination and Harassment by Managers and Employers}

This section examines respondents' narrated experiences of racist practices by supervisors, managers and/or employers. Precarious employment and work intersect here with discrimination and create specific sets of experiences. Analysis of the empirical material demonstrates how racialisation bears material consequences for workers against the background of intersecting regimes. Following Fiona Williams, the articulations of various regimes are here emphasised: 'A country's care regime intersects with its migration regime and its employment regime which provides the 
institutional context that shapes the experiences of both migrant women employed in domestic/care work and their employers, as well as the patterns of migrant care work to be found in different countries' (Williams 2014, p. 17, emphasis in original). The notion of migration regime encompasses both 'regulative and mobile practices of migration' (Rass and Wolff 2018, p. 22). Drawing further on Williams' definition, it is here understood as including migration policies, national norms and practices governing relationships between majority and minority groups, migrants' mobilisations and relevant national and transnational histories (Williams 2012, p. 371).

In all three national contexts, the vulnerabilities created by migration, employment and older-age care regimes generate specific implications for migrant and minority-ethnic workers along differentiated patterns. First, some of the ways in which managers dealt (or did not deal) with discrimination might amount, under certain circumstances, to racist discrimination. As foregrounded by MacQuarie's (2018) ethnography on night workers at a London grocery market, employers remain accountable for their turning a blind eye to certain practices, in this case exacerbating workers' precariousness. Several respondents recounted, for instance, being moved by the manager to another unit or floor in the case of racist attitudes by service users or colleagues. This, however, sent out the wrong message as to who was to blame and therefore weakened the position of the affected worker, who was further marginalised. In these cases, institutional practices effectively transformed the experience of individual prejudice into a form of institutional racism because of how the managers' position of power was used to entrench discriminatory outcomes. Such examples illustrate empirically that addressing racism in the workplace crucially requires managers' awareness and engagement for legal rights to be enforced. 'The transformation of racists themselves' that Balibar called for (Balibar and Wallerstein 1988, p. 29) requires the transformation of the majority group here that of employers' and managers' practices. For this purpose, it is crucial to analyse how these interactions are imbued in power relationships. The following paragraphs look into how intersecting elements such as the commercial context, migration statuses or live-in employment conditions play a role in shaping the power relationships within which racism manifests itself in interpersonal relations.

The commercial context of the private care homes in which most respondents in this study were employed, by transforming residents into customers, exacerbated the tensions engendered by the juxtaposition of vulnerable service users and precarious workers. The vulnerabilities created by migration policies and labourmarket segmentation, which weakened the position of workers, were deepened by the commercial context in which these relationships were embedded. Bacar clearly blamed this framework for the exacerbation of workers' vulnerability:

In for-profit care homes that make profits, so residents are clients; 'The client is the king', so they prefer clients to carers. Because the client makes the money go in, for the carer the employer pays out, he pays at the end of the month but clients pay in, so he prefers clients, the person who makes the money go in, that's logical. So if a carer has a problem with a patient or a resident or with the family, automatically it's the carer who's sanctioned, the client is always right (Bacar, 35, Senegal, Paris). 
In addition, managerial practices were at times directly discriminatory and ranged from unfair workloads to bullying and stigmatisation. In several cases a combination of these practices was present. The unfair division of tasks, as identified in the UK by Cangiano and his colleagues (2009, p. 137), constitutes a common form of discrimination in the care sector. This research also points out that unfair shift and annual-leave distributions are equally common discriminatory practices. Jade, who worked in Paris, complained that shifts and days off were assigned arbitrarily:

I would say that it is not fair. For instance, I can ask for a day off, one time it can be accepted, the other it's not. It's not fair, it's all I know; it's not fair. Annual leave, absences, no, it's not fair (Jade, 46, Ivory Coast, Paris).

Such management practices created resentment and impacted to varying degrees on workers' well-being. An unfair workload distribution could have serious health implications for the workers given the physical labour involved in care. Furthermore, migrant workers were undoubtedly exposed to specific forms of discrimination and exploitation due to the 'institutional insecurity' created by migration policies (Anderson 2010) within the group of racialised workers as a whole. The more dependent migrant workers were on their employer - e.g. to support the formers' work permits and provide their accommodation - the more they were exposed to abuse. A limited knowledge of their rights or a lack of language skills further worsened migrant workers' experiences. Isabel's first employer in the UK attempted to forcibly retain her in a job in which she faced abusive practices; she was required to work any shifts that the employer saw fit, as he had provided her with accommodation in a room adjacent to the care home and she had her wages withheld.

The environment is not really good. They are bullying, they are abusing us because they know that we are new and that we are foreigners. So we filed a resignation but they didn't accept it, they wanted us to stay though it is our right. If you're not happy you can go, yeah? We asked permission, we asked properly that we don't stay here any longer but they didn't allow us so we just leave (Isabel, 37, the Philippines, London).

Equally exposed to abuse, Sameera described how she felt oppressed in her workplace, where she experienced bullying but felt powerless and unable to challenge these behaviours; the stigma of being a migrant went beyond legal status. As Guillaumin (1972, p. 247, my translation) wrote several decades ago: 'Each individual who used to be a foreigner, alienated, condemned, always bears the scars of it, and his/her status of integration and conformism always remains ambiguous and submitted to the form of good will that constitutes tolerance or the silence of the majority'. Here, Sameera did not expect the planned acquisition of British citizenship to have any impact on how she would be perceived by managers and colleagues in the workplace and thus on their abusive attitudes towards her.

And me as migrant I can't even open my mouth, you understand? How can I? Because these people are more powerful than me. (...) Even though I've got ten years now, I'm married, my status changed, tomorrow I apply for British [citizenship], I will get it because my husband is British it's still ... I will be considered like different level, you understand? Because of my background, where I come from, because maybe of my skin colour, (...). This is always something which is always ... how can I say? ... Always inside you but you can't 
open your mouth and talk about it. Sometimes you feel you just want to shout, you want to explode. But what can you do? You're scared, you do your job (Sameera, 32, Mauritius, London).

The vulnerable position of migrant workers left a space for employers' arbitrariness given the very low probability that their practices would be sanctioned in any way. In London, Jenifer, who was born in the UK to Asian parents, highlighted a case of harassment of foreigners at her workplace:

And she [the manager] has been reported by several witnesses on one day, she went upstairs and was telling, because it's mostly Filipinos and a few Asian people on the first floor, she was going around and saying 'You're lucky, you're in your jobs otherwise you could be back home, if you're not happy where you're working you should go back home to your own country' (Jenifer, 24, the Philippines, London).

This harassment of the staff by a manager was more than xenophobia. The space for arbitrariness created by migration policies facilitated abuse in employer-employee relationships. Grace, employed in the same care home, made the point that bullying happens as a result of a power relationship:

She [the manager] doesn't do that [bullying] to the White ones who are there, like you know who can just drop everything and go. She doesn't do that to them. That's the difference; she doesn't insult them like that. She does it to the foreigners (Grace, 61, the Philippines, London).

Harassment by employers, including racist insults, was the most common in the narratives of migrant workers in Madrid employed in live-in caring arrangements. This employment situation constitutes an extreme form of imbalance between the employer and the employee, whereby the rights of the employee are extremely limited - on the one hand by employment legislation and migration rules and, on the other, by the material conditions of the employment relationship. A quite typical quote in this regard is that of Lucia, whose employer (a member of the family of the person she cared for) got angry and attacked her after she announced that she could not travel with the family to a Spanish island as planned because of a health issue:

She insulted me. She told me that we were only coming to steal, that I was a thief because she had bought me a uniform, she had bought me supplies. Because workers who worked in the house didn't eat in the house. They had a small separate house where domestic workers ate. Until they [employers] had finished eating, everything needed to be done and then you were going to the small house to have something to eat. It was a very difficult situation there (Lucia, 56, Nicaragua, Madrid).

The imbalance of power between the employer and the employee tends to be exacerbated in specific contexts: notably, when privatisation increases pressures to reduce labour costs, or when the employment relationship is situated in the domestic sphere for migrant workers employed as live-in carers. The articulation of care regimes and migration regulations thus created important differences as to care workers' exposure to employers' abuse. In Madrid, the domestic setting was particularly precarious due to workers' frequent dependence on their employers sustaining their legal statuses. With a focus on residential care provision most respondents in this research had been living in Spain for over 10 years, consequently 
the vast majority was able to obtain Spanish citizenship owing to post-colonial regulations for Latin American migrants. In London, those on student visas were at risk of loosing their legal status even in the case of continuous employment within the care sector as their employment did not provide sufficient earnings. In Paris, most had either a long-term residency permit (10 years) or had become French citizens. And yet, respondents' accounts in relation to managers' and employers' direct discrimination epitomise the reasons why anti-discrimination policies are de facto of very limited relevance when a large proportion of the workforce is trapped in segmented sections of the labour market on precarious employment terms. Even when working legally or after having obtained the citizenship of their country of residence, few migrant workers can afford to invest time and money individually in lengthy judicial procedures.

In addition, the statistics cited above demonstrated that such procedures are unlikely to bring about positive results in the UK and the absence of figures in the case of Spain and France revealed a lack of political will and transparency. While the discourses and practices around anti-discrimination legislation present notable differences in each of these countries, as outlined above, the structural vulnerabilities created by the intersection of migration/racialisation, employment and care regimes produced similar challenges for the everyday experiences of racialised workers in the three cities under study here. These negative work experiences were nevertheless resisted and fought against individually and collectively in creative ways. The following section looks at collective forms of coping with and resisting harassment and discrimination by managers.

\subsection{Challenging Racist Practices Collectively}

Seeking support outside the workplace is all the more difficult when targeted workers are denizens - i.e. have limited rights compared to citizens according to one's legal and economic status (De Genova 2013; Standing 2011). Faced with harassment by employers, it appears that respondents in Madrid mostly resorted to informal support groups and associations, while unions struggled to be present in this feminised sector of the labour market where a large share of migrant workers is present. In the masculinised sector of the night workers of a food market studied by MacQuarie (2018), unions were equally absent and workers knew little about their rights. Here, unions' weak presence was partly due to the inadequacy of the union's organising tools (e.g. meetings at times when workers could not attend, priorities that did not correspond to care workers' demands) as well as to care workers' isolation in the case of domestic workers. Often, the creation of such associations was the outgrowth of a previously existing informal group who aimed to alleviate domestic workers' isolation. Such organisations played a significant role in Madrid, where live-in care arrangements were commonplace. Victoria - who founded an 
association of migrant care workers - explained, for instance, how they were able to provide support to migrant care workers who had been dismissed by the family they were working for, in some cases after having been insulted and abused:

We had colleagues for whom it was very tough. They were told, 'What are you doing here? Go back to your country'. (...) They left their jobs and they were very depressed. We've been helping, I tell you, many women who came and whose situation was 'Look, they treated me like this, they told this or that'. Us, 'No, you have to cheer up, you're not like this and you have to carry on'. And we've worked, because we always had the luck to work with professional colleagues, we have a colleague who's a psychologist, others who used to be psychologists. So they've helped us with the women to make them realise that things are not as we're told (Victoria, 54, Ecuador, Madrid).

Mayra, also of Ecuadorian origin, joined a group of domestic workers in Madrid who met twice a month. She described how these contacts provided a powerful form of support:

We have an association, a group of women where we say we empower ourselves because we learn techniques and tricks to be able to endure the situation. It's not that it's to teach us but it's the experience of each one of us, amongst ourselves we've constructed a method to take care of ourselves for things that affect us at work (Mayra, 52, Ecuador, Madrid).

These forms of support were crucial for workers' well-being and, though they sometimes ushered in support for judicial proceedings, this was not their primary function. While unions could theoretically play that role, they were rarely mentioned by respondents in Madrid and did not act as a significant source of support in cases of harassment. Members of the association mentioned by Mayra were, for instance, rather critical of the role of unions, which they perceived as out-dated organisations unable to address the specific challenges of the highly feminised care and domestic-work sectors. One respondent, a victim of harassment in Madrid, thought of involving a union but her story shows that she was discouraged by the union itself from initiating a legal action:

NS: Were you thinking in this situation of seeking support, for example, from a union?

Rita: Yes, yes.

NS: What could they do in this situation?

Rita: I said I was about to denounce her for harassment because I knew that the union had to back me up. What happens is - and this is what the union told me - that if I go to court I need to be courageous. They told me 'If you go to court you need to be courageous because you go to court and this woman, she'll harass you even more than you can imagine, she'll harass you and harass you until she can prove that you're arrogant and, instead of you winning, she'll be the one winning. Do you take the risk of going to court?' Because the trial will take years, he told me. 'You might have left the care home but the trial will be going on for one, two, three or more years'. So I said: 'No, it's not like I got to the point that ... I'm not starving as much as to go to court' I said (Rita, 54, Ecuador, Madrid).

This story illustrates that cases of racist harassment are particularly difficult to challenge legally, even for unions. The mere existence of anti-discrimination legislation does not empower racialised workers because the path to employment tribunals is fraught with pitfalls. The reluctance of the union to start judicial proceedings seems to reflect its awareness of their limited effectiveness. At the same time it highlights 
again that most cases remain unchallenged (at least in legal terms) and thus unsanctioned.

In London, unions were described as potentially supportive institutions, even though no respondent actually resorted to a union for help - in some cases despite having joined a union following problems at work. Isabel, the Filipina care worker who experienced abuse in her first workplace in the UK, thought unions could have effectively supported her had she asked for help:

Because here in this country racism and bullying is a really big issue - they don't really allow it. It's not a crime but it's really a big issue for them. (...) I can get a big support from the union if I were a union member (...) because what I have experienced there is really racism, bullying, abuse (Isabel, 37, the Philippines, London).

However, in practice, the unions faced difficulties similar to those in Madrid, in spite of the stronger regulatory framework in the UK. Workers felt that it was difficult to prove discrimination, especially in cases of covert forms of racism. Furthermore, it was common amongst respondents in the UK to fear that joining a union would be perceived negatively by the management. When cases of discrimination did arise and the potential for confrontation through mediation by a union increased, this fear grew as well. Worry that making an allegation of discrimination would make the situation worse in the future discouraged Sameera from seeking the union's support:

NS: $\quad$ And did you get in touch with the union?

Sameera: No, I didn't because I was thinking if I have not resolved that problem, but thank God it was fine and I don't want to involve the union for anything because then there might be a grudge against me. If something which can't be resolved at all then I involve them, if not...but at the moment it's ok (Sameera, 32, Mauritius, London).

The commercialisation of unions' services, notably in the UK, also played a role in diminishing the trust which workers could place in unions: if union membership was a cost/benefit calculation for unions (and for workers), then the likelihood of obtaining the union's support for a costly and uncertain procedure was perceived as low. This paradox may be the most prominent in the UK; despite the existence of well-developed anti-discrimination legislation encompassing a wide range of possible forms of discrimination, the possibility of lodging a complaint with an employment tribunal is hampered by a series of structural characteristics of the UK employment regime. These include low levels of employment protection compared to other European countries, costly judicial procedures and a low probability of obtaining union support, given that the chances of winning discrimination cases are generally low and that unions take that variable into account. Willing to support her care assistant colleagues who were harassed by the manager of the care home she worked in, Grace did not assess positively the potential role of unions:

Everybody is making money, even unions sometimes they're making money, they collect all the membership and they don't support you when you need them, they're collecting money, everything is business nowadays. So when it comes to litigations, when it comes to spending so much money to fight your case, goodbye to you, they don't want to know. (...) Unless you're a strong person who can go through this hassle and this trouble, forget it, because it's 
a very lengthy procedure and you need a lot of evidence to prove that (Grace, 61, the Philippines, London).

It thus appears that, when discrimination and abuse do happen, these rights are often barely accessible, notwithstanding the level of development of the regulatory framework. Existing power relationships make it difficult for workers to challenge their managers and employers. The difficulty of proving discrimination and harassment adds to the problem and to the fear of starting a procedure in vain, thus risking exposure to more abuse.

\subsection{Conclusion}

My analysis of various forms of racism and discrimination and of the consequent coping strategies revealed how these are in fact interrelated and are symptomatic of broader institutional racism. Exploring situations of harassment and abuse by colleagues highlighted common manifestations of racism and discrimination and exposed some of their implications for workers' well-being. This chapter pointed out how these experiences were embedded in workplace power relationships and identified the role played by managers and employers in different situations. In none of the cases analysed here did bullying and harassment by colleagues usher in disciplinary procedures or legal cases. The second aspect - that of direct discrimination or harassment by managers - highlighted how intersecting migration, care and employment regimes fostered abuse at the workplace level by exacerbating precariousness. Migrant workers were the most exposed to direct harassment by managers. Against the background of disempowering processes fostered by labour market fragmentation, racialised care workers are left with limited options to challenge racist discrimination by employers or racist remarks by colleagues. The institutional indifference to care workers' experiences of racism not only fosters disintegration but also undermines the effectiveness of anti-discrimination legislation.

This chapter argues in this regard that experiencing racism on a daily basis, with little leverage to challenge it, constitutes a disintegrating mechanism. The chapter demonstrated that anti-discrimination legislation often remains out of reach for racialised precarious workers and that anti-racism is too often reduced to the legal framework of anti-discrimination policies, falling short of analysing the structural dynamics that foster racism at multiple levels. By defining migrant workers' rights, employment and migration regimes shape the conditions for workers' exposure to racist discrimination, harassment and abuse. Challenging these situations is complex and no single framework can improve workers' experiences from all these perspectives. Anti-discrimination legislation appears to be of very limited efficacy for precarious workers: in spite of the numerous experiences related by respondents in this research, no one actually resorted to anti-discrimination legislation. The great majority of cases remain unchallenged, which suggests that it is difficult to fix structurally unequal power relationships through individual legal action. Moreover, most 
abusive situations are created or exacerbated by the space for arbitrariness derived from the articulation of migration and employment policies. Therefore, overstating the relevance of anti-discrimination legislation, and its potentially integrative effects, runs the risk of equating anti-racism with anti-discrimination policies, instead of conducting a political economy analysis of the material conditions under which racism and discrimination thrive. As argued in the introduction to this volume (Collyer et al. 2020) integration and disintegration are deeply entangled; this chapter demonstrated in this regard that anti-discrimination legislation fulfils a discursive purpose but is of limited relevance to the experiences of racialised workers and thus comes to play an ambiguous role in the politics of (dis)integration. Challenging racism and racist discrimination cannot rely solely on an anti-discrimination legislative framework. Low levels of employment protection weaken migrants' possibilities for denouncing an employer for harassment, due to the unfavourable power relationship thus established. Support mechanisms at the workplace level can include greater presence of trade unions and support organisations as well as protective whistleblowing policies. Overall, migrant and minority-ethnic workers' inclusion crucially depends on empowering workers through employment protection, reducing the precariousness of their migration statuses and improving their access to the judicial system through administrative and financial support. As long as legal protections do not effectively challenge the marginalisation of racialised care workers and the neglect of their experiences of racism they will continue to feed into the politics of (dis)integration.

\section{References}

Anderson, B. (2010). Migration, immigration controls and the fashioning of precarious workers. Work, Employment and Society, 24(2), 300-317.

Anthias, F., \& Yuval-Davis, N. (1992). Racialized boundaries: Race, nation, gender, colour and class and the anti-racist struggle. London: Routledge.

Aspinall, P. J. (2002). Collective terminology to describe the minority ethnic population: The persistence of confusion and ambiguity in usage. Sociology, 36(4), 803-816.

Balibar, E., \& Wallerstein, I. M. (1988). Race, Nation, Classe: Les Identités Ambiguës. Paris: Ed. La Découverte.

Boyatzis, R. E. (1998). Transforming qualitative information: Thematic analysis and code development. London: Sage.

Byrd, C. (2011). Conflating apples and oranges: Understanding modern forms of racism. Sociology Compass, 5(11), 1005-1017.

Cangiano, A., Shutes, I., Spencer, S., \& Leeson, G. (2009). Migrant care workers in ageing societies: Research findings in the United Kingdom. Oxford: University of Oxford, COMPAS Report.

Carlmicheal, S., \& Hamilton, C. V. (1967/1992). Black power. The politics of liberation. New York: Vintage Books.

Colectivo Ioé. (2003). Experiencias de Discriminación de Minorías Étnicas en España. Retrieved in August 2018 from https://www.colectivoioe.org/uploads/edb969a5b5bb4f6aaf3f9afb865cf396533d9315.pdf

Collyer, M., Hinger, S., \& Schweitzer, R. (2020). Politics of (dis)integration - An introduction. In S. Hinger \& R. Schweitzer (Eds.), Politics of (dis)integration (pp. 1-18). Cham: Springer VS. 
De Genova, N. (2013). Spectacles of migrant 'illegality': The scene of exclusion, the obscene of inclusion. Ethnic and Racial Studies, 36(7), 1180-1198.

Department for Business Innovation and Skills. (2014). Findings from the survey of tribunal employment applications 2013. Research series no. 177. Retrieved in August 2018 from https://assets.publishing.service.gov.uk/government/uploads/system/uploads/attachment_data/ file/316704/bis-14-708-survey-of-employment-tribunal-applications-2013.pdf

Duggan, L. (2003). The twilight of equality. Neoliberalism, cultural politics and the attack on democracy. Boston: Beacon Press Books.

Ehrenreich, B., \& Hochschild, A. R. (2002). Global woman: Nannies, maids, and sex workers in the new economy. New York: Holt Press.

Foucault, M. (2004). Naissance de la Biopolitique. Cours au Collège de France, 1978-1979. Paris: Seuil/Gallimard.

Fraser, N. (2016). Contradictions of capital and care. New Left Review, 100, 99-117.

Gawronski, B., Peters, K. R., Brochu, P. M., \& Strack, F. (2008). Understanding the relations between different forms of racial prejudice: A cognitive consistency perspective. Personality and Social Psychology Bulletin, 34(5), 648-665.

Gilroy, P. (1987/2002). There ain't no black in the Union Jack. London: Routledge.

Guillaumin, C. (1972/2002). L'idéologie raciste. Paris: Editions Folios Essais.

HALDE. (2010). Rapport annuel HALDE 2010. Paris: La Documention Française. Retrieved in August 2018 from http://www.ladocumentationfrancaise.fr/var/storage/rapports-publics/114000234.pdf

Hall, S. (1978). Racism and reaction. In BBC TV/Commission for Racial Equality (Ed.), Five views of multi-racial Britain (pp. 23-35). London: Commission for Racial Equality.

Headley, C. (2000). Philosophical approaches to racism: A critique of the individualistic perspective. Journal of Social Philosophy, 31(2), 223-257.

Ikuenobe, P. (2010). Conceptualizing racism and its subtle forms. Journal for the Theory of Social Behaviour, 41(2), 161-181.

Lentin, A., \& Titley, G. (2011). The crises of multiculturalism: Racism in a neoliberal age. New York: Zed Books.

MacQuarie, J.-C. (2018). Invisible migrants: Glocturnal cities' 'other workers' in the postcircadian capitalist era. $\mathrm{PhD}$ thesis. Budapest: Central European University. Retrieved 1 April 2019 from https://bit.ly/2FCMkFX

McCall, L. (2005). The complexity of intersectionality. Journal of Women and Culture in Society, 30(3), 1771-1800.

Ministerio de Sanidad, Política Social e Igualdad. (2011). Informe anual sobre la situación de la discriminación y la aplicación del principio de igualdad de trato por origen racial o étnico en España. Madrid: Ministerio de Sanidad, Politica Social e Igualdad. Retrieved in August 2018 from http://www.mscbs.gob.es/ssi/igualdadOportunidades/docs/2010_Informe_Anual_ Consejoigualdad_Accesible.pdf.

Ministry of Justice. (2012). Employment tribunals and EAT statistics, 2011-12. London: Ministry of Justice. Retrieved in August 2018 from https://assets.publishing.service.gov.uk/government/uploads/system/uploads/attachment_data/file/218497/employment-trib-stats-aprilmarch-2011-12.pdf.

Nimführ, S., Otto, L., \& Samateh, G. (2020). Denying, while demanding integration: An analysis of the integration paradox in Malta and refugees' coping strategies. In S. Hinger \& R. Schweitzer (Eds.), Politics of (dis)integration (pp. 161-181). Cham: Springer VS.

Parreñas, R. (2000). Migrant Filipina domestic workers and the international division of reproductive labor. Gender \& Society, 14(4), 560-580.

Rass, C., \& Wolff, F. (2018). What is in a migration regime? Genealogical approach and methodological proposal. In A. Pott, C. Rass, \& F. Wolff (Eds.), Was ist ein Migrationsregime? (What is a migration regime?) (pp. 19-64). Osnabrück: Springer.

Rattansi, A. (2011). Multiculturalism: A very short introduction. Oxford: Oxford University Press. 
Renton, D. (2013). Culture of disbelief? Why race discrimination claims fail in the employment tribunal. London: Institute of Race Relations. Retrieved in August 2018 from http://www.irr.org.uk/ news/culture-of-disbelief-why-race-discrimination-claims-fail-in-the-employment-tribunal/.

Sahraoui, N. (forthcoming). Racialised workers and European older-age care from care labour to care ethics. London: Palgrave Macmillan.

Schweitzer, R. (2020). How inclusive institutions enforce exclusive immigration rules: Mainstream public service provision and the implementation of a hostile environment for irregular migrants living in Britain. In S. Hinger \& R. Schweitzer (Eds.), Politics of (dis)integration (pp. 121140). Cham: Springer VS.

Sivanandan, A. (1985). RAT and the degradation of black struggle. Race \& Class, 26(4), 1-33.

Smith, D. E. (2005). Institutional ethnography: A sociology for people. Oxford: Altamira Press.

Spitálszky, A. (2013). Racism and related discriminatory practices in employment in Spain. Brussels: European Network Against Racism. Retrieved in August 2018 from http://www.enareu.org/IMG/pdf/spain.pdf.

Standing, G. (2011). The precariat: The new dangerous class. London: Bloomsbury Academic.

Thelwell, E. (2015, March 12). Are race discrimination laws still needed in the workplace? BBC News Online. Retrieved in August 2018 from http://www.bbc.com/news/uk-31856147

Williams, F. (2012). Converging variations in migrant care work in Europe. Journal of European Social Policy, 22(4), 363-376.

Williams, F. (2014). Making connections across the transnational political economy of care. In B. Anderson \& I. Shutes (Eds.), Migration and care labour: Theory, policy and politics (pp. 11-30). Hampshire: Palgrave Macmillan.

Open Access This chapter is licensed under the terms of the Creative Commons Attribution 4.0 International License (http://creativecommons.org/licenses/by/4.0/), which permits use, sharing, adaptation, distribution and reproduction in any medium or format, as long as you give appropriate credit to the original author(s) and the source, provide a link to the Creative Commons licence and indicate if changes were made.

The images or other third party material in this chapter are included in the chapter's Creative Commons licence, unless indicated otherwise in a credit line to the material. If material is not included in the chapter's Creative Commons licence and your intended use is not permitted by statutory regulation or exceeds the permitted use, you will need to obtain permission directly from the copyright holder.

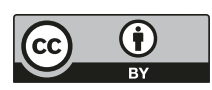

